\title{
PENGEMBANGAN MEDIA GOOGLE SITE DALAM BIMBINGAN KLASIKAL DI SMAN 1 SAMPUNG
}

\author{
Bambang Setyawan \\ SMA Negeri 1 Sampung \\ setyawanafifah9@gmail.com
}

\begin{abstract}
This development aims to produce a classical guidance media that can be accessed through smartphones and meets the elements of eligibility through expert user trials, and field trials. In addition, through this development activity, it is also expected to provide positive internet content. The development model adapts the ASSURE concept, namely through steps: analyzing students' characteristics, standards and goals, choosing strategy-technology-media and materials, using technology, media and materials, requiring student participation, evaluating and revising. The feasibility test, based on the ACTIONS concept, produces a score of 317 with a maximum score of 340 , the eligibility level reaches $93 \%$. While from the field test conducted in XII Science 1 with the main focus of observation on the active behavior, the total score is 1417 with a maximum score of 1450 , the level of activity is $97.72 \%$. Based on the results of expert tests by certified BK teachers and data from field test results, it was found that the website with google site was accepted and suitable as a classical guidance media. To get wider benefits it is recommended to arrange media for other material content.
\end{abstract}

\footnotetext{
ABSTRAK

Pengembangan ini bertujuan untuk menghasilkan media bimbingan klasikal yang dapat diakses melalui smartphone dan memenuhi unsur-unsur kelayakan melalui uji coba ahli pengguna, dan uji coba lapangan. Selain itu, melalui kegiatan pengembangan ini, diharapkan juga dapat memberikan konten internet yang positif. Model pengembangan mengadaptasi konsep ASSURE, yaitu melalui langkahlangkah: menganalisis karakteristik peserta didik, standar dan tujuan, memilih strategi-teknologi-media dan bahan, menggunakan teknologi, media dan bahan, memerlukan partisipasi peserta didik, mengevaluasi dan merevisi. Uji kelayakan, berdasarkan konsep ACTIONS, menghasilkan skor 317 dengan skor maksimum 340 , tingkat kelayakan mencapai $93 \%$. Sedangkan dari uji lapangan yang dilakukan di kelas XII IPA 1 dengan fokus utama pengamatan terhadap indikator perilaku keaktifan, skor total 1417 dengan skor maksimum 1450, tingkat aktivitas adalah $97,72 \%$. Berdasarkan hasil uji ahli oleh guru BK yang sudah bersertifikat pendidik dan data hasil uji lapangan, ditemukan bahwa media web google site diterima dan cocok sebagai media bimbingan klasikal. Untuk mendapatkan manfaat yang lebih luas disarankan menyusun media untuk konten materi lainnya.
}

Keywords:

media, classical guidance, google site

Kata Kunci: media, bimbingan klasikal, google site 


\section{PENDAHULUAN}

Dalam buku Panduan Operasional Penyelenggaraan Bimbingan dan Konseling Sekolah Menengah Atas (SMA), bimbingan klasikal merupakan salah satu bagian bimbingan dan konseling yang diselenggarakan dengan cara tatap muka di dalam kelas. Layanan bimbingan klasikal ini dilaksanakan secara terjadwal dan rutin 2 (dua) jam setiap kelas perminggu (Pedoman BK PDPM, 2016). Pada praktek di sekolah, amanat dalam buku pedoman tersebut belum sepenuhnya dapat direalisasikan. Saat pertemuan rutin dalam Musyawarah Guru BK (MGBK), tidak sedikit guru BK yang mengeluhkan jadwal rutin masuk kelas. Ada sekolah yang menjadwalkan 1 jam untuk BK di semua jenjang kelas, ada juga sekolah yang menjadwalkan 1 jam untuk jenjang kelas tertentu namun ada juga yang sama sekali tidak menjadwalkan BK untuk masuk kelas. SMAN 1 Sampung misalnya, di kelas $X$ telah dijadwalkan masuk kelas rutin 1 jam pembelajaran, untuk kelas XI belum mendapatkan jadwal masuk kelas, berbeda lagi dengan kelas XII harus berbagi dengan mata pelajaran PJOK, memberikan layanan klasikal 2 (dua) pekan sekali padahal untuk kelas XII diperlukan bimbingan intensif terkait pendidikan lanjutan. Namun demikian bimbingan klasikal merupakan sarana strategis untuk mendekatkan guru BK dengan kelompok kelas, mengamati keunikan karakteristik setiap peserta didik, mengembangkan potensi siswa dengan strategi yang mengutamakan pencegahan, perbaikan dan penyembuhan, pemeliharaan dan atau pengembangan. Bisa dibayangkan apabila guru BK yang bertugas memfasilitasi tercapainya tugas perkembangan peserta didik tidak diberikan kesempatan masuk kelas secara rutin dan terjadwal maka asesmen terhadap sikap, perilaku dan keunikan masing-masing peserta didik tidak akan mampu berjalan dengan optimal, padahal melalui asesmen tersebut menjadi dasar perencanaan program dan penentuan strategi bantuan bagi peserta didik yang efektif dan efisien. Selain itu tanpa masuk kelas pemberian informasi maupun pengetahuan yang berkaitan dengan diri pribadi siswa, lingkungan sosial, lingkungan belajar dan kesiapan karier tidak akan tersampaikan secara optimal. Dimana informasi-informasi tersebut mungkin saja dibutuhkan sesuai dengan analisis hasil asesmen peserta didik di sekolah.

Keterbatasan kesempatan untuk memberikan bimbingan klasikal tersebut seyogyanya tidak membuat pelaksanaannya asal-asalan. Penyelenggaraan bimbingan klasikal yang efektif dan efisien dengan memanfaatkan segala strategi dan media merupakan salah satu wujud profesionalisme guru BK. Cakap dalam akademik dan senantiasa meningkatkan kompetensi profesional adalah amanat dalam standar kualifikasi akademik profesi guru BK ataupun konselor di sekolah yang tercantum dalam Permendiknas No 27 Tahun 2018. Sebagai jabatan profesional tentunya guru BK harus mampu memanfaatkan kemajuan teknologi untuk memberikan pelayanan. Sehingga semakin berkembangnya zaman guru BK akan tetap menjadi primadona bagi peserta didiknya. Menurut American School Counseling Association (dalam Zimoek, 2016) konselor sekolah perlu memiliki kompetensi dibidang teknologi, guru BK dituntut untuk selalu memperbaharui pengetahuan dan keterampilan, baik pengetahuan mengenai karakteristik unik yang membedakan antara peserta didik era kemarin dengan era digitalisasi maupun keterampilan menggunakan teknologi untuk mengoptimalkan pelaksanaan bimbingan klasikal. Oleh karena itu sudah semestinya guru BK sebagai fasilitator tercapainya 
kemandirian peserta didik mampu memanfaatkan kemajuan teknologi guna mengoptimalkan bimbingan klasikal.

Sink, C. A. (dalam Rakhmawati, D., 2017: 61) mengutarakan bahwa kehidupan abad 21 yang serba mudah, mendorong konselor sekolah untuk tetap fokus pada 8 (delapan) hal: 1) mengembangkan dan memperbarui keterampilan yang dibutuhkan untuk melayani semua siswa; 2) menjelajahi inovasi dalam pendidikan serta kemampuan memahami teori konseling dan mempraktekkannya dengan cakap; 3) advokasi untuk diri mereka sendiri dan program mereka, 4) melaksanakan program yang komprehensif yang dirancang dengan baik; 5) berkolaborasi dengan pihak lain, personil sekolah, dan dengan lembaga-lembaga dan program masyarakat; 6) memfasilitasi siswa baik kebutuhan maupun program prestasi; 7) membuat komunitas yang nyaman di sekolah; 8) menunjukkan profesionalisme tingkat tinggi. Untuk itu diperlukan strategi penyelenggaraan bimbingan klasikal yang menarik dan mampu meningkatkan keaktifan siswa sehingga mendorong tujuan layanan dapat tercapai. Salah satu dasar memilih suatu media dalam bimbingan klasikal adalah dengan mengetahui karakterisik peserta didik saat ini. Peserta didik kita saat ini adalah pribadi yang lahir tumbuh berkembang dengan teknologi, yang juga sering disebut dengan generasi net (internet). Setidaknya ada 5 hal yang menjadi ciri khas generasi net tersebut, sebagaimana yang diungkapkan Susana (2012:57) diantaranya generasi yang mampu memperoleh berbagai informasi dari berbagai sumber dengan cepat, ciri kedua yaitu generasi yang mampu bekerja secara multitasking, ciri ketiga ketertarikan yang lebih terhadap multimedia, ciri keempat hampir menjangkiti seluruh usia yaitu segala aktifitas dan pola interaksi yang dulu cenderung di dunia nyata, kini beralih melalui dunia maya melalui media sosial, ciri terakhir dalam hal belajar, mereka cenderung tertarik dan menunjukkan minat yang lebih tinggi terhadap sesuatu yang selain aplikatif juga bersifat menyenangkan.

Perusahaan yang bergerak dalam bidang internet dan dan teknologi multinasional dari Amerika Serikat yang sudah familiar dengan keseharian kita (google) menawarkan layanan untuk membuat website mudah (tanpa memerlukan keahlian bahasa pemrograman) dan gratis yaitu google site. Melalui media website dengan google site guru BK dapat membuat media bimbingan klasikal, lebih dari itu juga membuat konten positif yang dapat dimanfaatkan oleh peserta didik melalui smartphone setiap saat. Integrasi google site dengan layanan google lainnya (google form) memungkinkan guru BK untuk melancarkan berbagai asesmen baik testing maupun non testing. Selain menjadi media aplikasi instrumentasi, guru BK juga bisa memasukkan materi berupa gambar, animasi, berbagai tayangan video ataupun sinema pendek untuk memberikan layanan klasikal kepada peserta didik baik selama berada di kelas maupun sudah berada di luar kelas dengan fasilitas smartphone dan jaringan internet. Kegiatan pengembangan media web berbasis google site dimaksudkan untuk menghasilkan media bimbingan peserta didik secara klasikal yang layak digunakan dan mampu meningkatkan partisipasi siswa dalam bimbingan klasikal. Pengukuran keefektifan media website berbasis google site dalam bimbingan klasikal berdasar pada konsep strategi pemanfaatan media ACTIONS (Access, Cost, Teaching \& Learning Functions, Interactive, Organization, Novelty, 
Speed) yang dikemukakan oleh Tony Bates (1995). Secara operasional prinsip media pembelajaran ACTIONS diuraikan pada tabel berikut.

Tabel 1. Akronim proses ACTION

\begin{tabular}{cll}
\hline A & Acces & $\begin{array}{l}\text { Seberapa mudah untuk dapat diakses? Seberapa fleksibel untuk digunakan } \\
\text { oleh kelompok tertentu? }\end{array}$ \\
\hline C & Cost & Berapa biaya yang diperlukan untuk pembuatan dan pemanfaatan? \\
\hline T & $\begin{array}{l}\text { Teaching \& } \\
\text { Learning Functions }\end{array}$ & $\begin{array}{l}\text { Jenis pembelajaran apa yang dibutuhkan? Apakah pendekatan instructional } \\
\text { akan memenuhi kebutuhan ini? Teknologi seperti apa yang dapat } \\
\text { mendukung tercapainya tujuan pembelajaran? }\end{array}$ \\
\hline I & Interactivity and & $\begin{array}{l}\text { Interaksi seperti apa yang dimungkinkan oleh teknologi ini? Seberapa } \\
\text { mudah digunakan? }\end{array}$ \\
\hline O & Oser Friendliness & $\begin{array}{l}\text { Apa saja persyaratan dan hambatan yang harus dihilangkan, sebelum } \\
\text { teknologi ini bisa }\end{array}$ \\
& & berhasil digunakan? \\
\hline $\mathrm{N}$ & Novelty & Seberapa baru teknologinya? \\
\hline S & Speed & $\begin{array}{l}\text { Seberapa cepat media dapat digunakan? Seberapa cepat material dapat } \\
\text { diubah? }\end{array}$ \\
\hline
\end{tabular}

Prinsip pengembangan media pembelajaran ACTIONS ini dirasa sangat relevan dengan manfaat dan tujuan pengembangan media bimbingan klasikal berbasis website google site. Dimana dengan menerapkan prinsip ini, media online yang dikembangkan dapat benarbenar memenuhi unsur kelayakan. Media yang dikembangkan benar-benar mempertimbangkan sekaligus memenuhi berbagai aspek yang mendukung penggunaan, baik dari sisi kemudahan dan kekinian. Secara operasional media dapat dibuat dengan fasilitas yang secara teknis sudah tersedia dengan representatif di sekolahan yaitu perangkat komputer, jaringan internet yang cepat dan stabil.

\section{METODE}

Desain rancangan dalam kegiatan pengembangan ini mengadaptasi model pengembangan ASSURE. Desain pengembangan model ASSURE selain disebut ancangan untuk kegiatan belajar mengajar juga merupakan model pengembangan media yang berorientasi kelas. Terdapat enam tahap dalam model pengembangan ini sebagaimana yang disebutkan Heinich et al (2005) yaitu: 1) Menganalisis karakteristik peserta didik sebagai subyek belajar; 2) Menetapkan standard dan obyektifitas media; 3) memilih strategi, kebermanfaatan teknologi dan materi; 4) penggunaan teknologi media dan materi; 5) Membutuhkan partisipasi peserta didik dalam hal ini memerlukan implementasi sebagai bentuk uji media di kelas; 6) sedangkan yang terakhir adalah melakukan evaluasi terhadap media yang telah diuji cobakan sebagai dasar untuk melakukan perbaikan. Menurut teori, model pengembangan ASSURE adalah model pengembangan media pembelajaran. Meskipun begitu model ini juga cocok untuk dijadikan acuan inovasi dalam pembuatan media bimbingan klasikal, karena model ASSURE ini memulai pembuatan media dengan asesmen karakteristik dan kebutuhan peserta didik calon pengguna media, menerapkan teknologi dan ketersediaan fasilitas hingga mengevaluasi dan merivisi produk media. Secara prinsip memang layanan bimbingan klasikal berbeda dengan kegiatan belajar mengajar pada mata pelajaran, namun juga terdapat kesamaan yaitu samasama kegiatan yang beorientasi kelas. Sehingga model pengembangan ASSURE ini juga dapat dijadikan acuan guru BK untuk menyusun media bimbingan klasikal. 
Kegiatan pengembangan ini dimulai dari asesmen kriteria peserta didik dan fasilitas yang tersedia di kelas, merumuskan standar dan tujuan pengembangan, memilih teknologi dan materi yang akan disampaikan, proses pembuatan media, mengimplementasi kemudian mengevalusi dan merevisi media. Sedangkan untuk pembuatan media melalui langkah-langkah yang disesuaikan dengan langkah praktis penyusunan google site Satu Guru Satu Inovasi (Sagusanov) Ikatan Guru Indonesia (IGI), diantaranya mengawali kegiatan dengan menyusun desain interaksi. Desain interaksi merupakan panduan, bisa juga disebut sebagai skenario interaksi laman satu dengan laman yang lainnya. Dalam desain interaksi juga ditentukan jumlah laman yang dibuat berikut dengan kontennya. Halaman yang dibuat dalam media web berbasis google site ini diantaranya halaman beranda berisi daftar isi, halaman pengertian, halaman subjudul, halaman asesmen dan evaluasi yang berisi instrumen percaya diri dan evaluasi hasil, halaman pustaka dan halaman inovator. Pada halaman beranda terdapat daftar isi berupa tombol aktif ke semua halaman, sehingga dari beranda pengguna bisa menuju ke halaman yang dikehendaki dengan sekali sentuh. Selain itu di setiap halaman berikutnya terdapat tombol aktif untuk lanjut ke halaman berikutnya atau kembali ke halaman sebelumnya, juga memungkinkan kembali ke beranda. Melalui instrumen asesmen yang terintegrasi dalam halaman google site memungkinkan pengguna mengetahui hasil secara langsung, juga otomatis tersimpan dalam drive penyusun. Pada prinsipnya media web dengan google site ini bersifat dinamis, sehingga penyusun dapat merubah konten setiap saat sesuai dengan kebutuhan dan kekinian. Daya tarik juga didapat dari penambahan gambar, animasi, suara bahkan video ataupun sinema pendek baik dengan cara upload sendiri maupun menghubungkan link youtube ke halaman site.

Subyek dalam kegiatan penyusunan media bimbingan dalam seting klasikal ada dua: 1) subyek uji ahli yaitu guru BK yang telah bersertifikat pendidik; 2) subyek uji coba implementasi media di kelas yaitu peserta didik kelas XII IPA 1. Uji coba ahli atau pengguna dilakukan untuk mengetahui tingkat kelayakan penggunaan media di kelas. Uji kelayakan media dilakukan oleh empat ahli yaitu 4 guru BK yang telah bersertifikat pendidik. Sedangkan uji coba implementasi media di kelas (uji lapangan) dilakukan dengan memantau perilaku aktif peserta didik selama mengikuti bimbingan klasikal dengan media yang dihasilkan. Instrumen pengumpulan data dalam kegiatan penyusunan media web berbasis google site yaitu: 1) angket uji ahli, untuk mengetahui tingkat kelayakan media yang berpedoman pada kriteria Acces, Cost, Teaching \& Learning Functions, Interactivity and User Friendliness, Organization, Novelty, Speed (ACTIONS); 2) Instrumen pengamatan perilaku aktif peserta didik saat implementasi media. Ada 10 indikator untuk mengukur perilaku aktif selama proses bimbingan klasikal yaitu: a) siswa membawa smartphone; b) siswa mendengar dan melaksanakan instruksi dari guru BK; c) smartphone siswa dapat terhubung dengan wifi kelas; d) siswa dapat mengakses halaman google site yang telah dishare guru BK; e) siswa tampak mempelajari setiap halaman google site di smartphone masing-masing; f) siswa tampak lancar mengakses materi dalam google site; g) siswa mengerjakan instrumen percaya diri dalam google site di smartphone masingmasing; h) siswa dapat melihat skor tingkat percaya diri melalui smartphone masing-masing; i) siswa nyaman mengakses materi tentang $A Q$ di smartphone nya masing-masing; j) siswa menyatakan mendukung digitalisasi materi pada layanan klasikal. 
Data yang merupakan hasil dari uji ahli dan uji implementasi di kelas terhadap media yang dikembangkan dianalisis secara deskriptif untuk mengetahui tingkat kelayakan produk pengembangan, serta bahan untuk memperbaiki/merevisi produk yang telah berhasil dikembangkan. Selain itu, data hasil uji implementasi di kelas terhadap media yang dikembangkan juga digunakan untuk mengetahui tingkat antusiasme dan tingkat kemunculan perilaku aktif peserta didik dalam bimbingan klasikal menggunakan media google site. Tingkat kelayakan dan revisi produk berpedoman pada kriteria tingkat kevalidan dan revisi produk (Ari Kunto, 2006:276)

\section{Tabel 2. Kategori Kelayakan Produk}

\begin{tabular}{cc}
\hline Persentase (\%) & Kriteria Validasi \\
\hline $76-100$ & Valid (tidak perlu revisi) \\
\hline $56-75$ & Cukup Valid (tidak perlu revisi) \\
\hline $40-55$ & Kurang Valid (Revisi) \\
\hline $0-39$ & Tidak Valid (Revisi) \\
\hline
\end{tabular}

\section{HASIL}

Hasil penelitian pada dasarnya merupakan serangkaian proses dalam mengatur dan usaha untuk mengklasifikasikan pengetahuan yang didapat sesuai dengan temuan-temuan yang diperoleh selama kegiatan pengembangan. Temuan-temuan tersebut menjadi fakta dalam kegiatan yang telah dilakukan sehingga berdasarkan fakta-fakta tersebut dapat ditarik kesimpulan-kesimpulan kegiatan pengembangan yang dapat menjawab rumusan masalah suatu kegiatan penelitian maupun pengembangan. Pada bagian ini akan disampaikan data hasil uji kelayakan media oleh empat guru BK yang bersertifikat pendidik dan data hasil uji implementasi media di kelas yang dilakukan berdasarkan pengamatan terhadap sepuluh perilaku aktif yang dimunculkan oleh peserta didik selama mengikuti layanan. Data yang diperoleh dari uji kelayakan oleh 4 guru BK bersertifikat pendidik disajikan dalam tabel sebagai berikut:

\section{Tabel 3. Hasil Uji Kelayakan Produk}

\begin{tabular}{|c|c|c|c|c|c|}
\hline \multirow{2}{*}{ No } & \multirow{2}{*}{ Indikator } & \multicolumn{4}{|c|}{ Skor } \\
\hline & & 1 & 2 & 3 & 4 \\
\hline 1 & Acces & 10 & 10 & 9 & 9 \\
\hline 2 & Cost & 10 & 10 & 10 & 10 \\
\hline 3 & Teaching \& Leaming Functions & 10 & 10 & 8 & 9 \\
\hline 4 & Interactivity and User Friendliness & 15 & 14 & 12 & 15 \\
\hline 5 & Organization & 10 & 8 & 8 & 10 \\
\hline 6 & Novelty & 15 & 15 & 12 & 14 \\
\hline 7 & Speed & 15 & 13 & 13 & 13 \\
\hline & Total & 85 & 80 & 72 & 80 \\
\hline & Skor Maksimal & 85 & 85 & 85 & 85 \\
\hline
\end{tabular}

Berdasarkan hasil yang tertera pada tabel di atas, dapat diketahui bahwa: 1) hasil uji kelayakan media oleh ahli pertama mendapatkan skor 85 (skor maksimal) sehingga tingkat kelayakan dari pengguna pertama mencapai $100 \%$; 2) ahli kedua mendapatkan skor 80 , sehingga tingkat kelayakan dari pengguna kedua 94\%; 3) ahli ketiga mendapatkan skor 72 , 
sehingga tingkat kelayakan dari pengguna ketiga 84\%; 4) ahli keempat mendapatkan skor 80, sehingga tingkat kelayakan dari pengguna keempat $94 \%$. Sehingga dari uji kelayakan secara keseluruhan diperoleh angka 317 dengan skor maksimal 340, tingkat kelayakan mencapai 93\%. Sedangkan pada kegiatan uji lapangan dengan pengamatan terhadap 10 indikator perilaku keaktifan, diperoleh data sebagai berikut:

Tabel 4. Hasil Uji Lapangan

\begin{tabular}{|c|c|c|c|}
\hline No & Aspek Perilaku Aktif & $\begin{array}{c}\text { Skor } \\
\text { maksimal }\end{array}$ & $\begin{array}{c}\text { Skor } \\
\text { diperoleh }\end{array}$ \\
\hline 1 & Siswa membawa smartphone & 145 & 145 \\
\hline 2 & Siswa mendengar instruksi dari guru BK & 145 & 119 \\
\hline 3 & Smartphone siswa dapat terhubung dengan wifi kelas & 145 & 145 \\
\hline 4 & $\begin{array}{l}\text { Siswa dapat mengakses halaman google site yang telah dishare } \\
\text { guru BK }\end{array}$ & 145 & 145 \\
\hline 5 & $\begin{array}{l}\text { Siswa tampak mempelajari setiap halaman google site di } \\
\text { smartphone masing-masing }\end{array}$ & 145 & 145 \\
\hline 6 & Siswa tampak lancar mengakses materi dalam google site & 145 & 142 \\
\hline 7 & $\begin{array}{l}\text { Siswa mengerjakan instrumen percaya diri dalam google site di } \\
\text { smartphone masing-masing }\end{array}$ & 145 & 145 \\
\hline 8 & $\begin{array}{l}\text { Siswa dapat melihat skor tingkat percaya diri di smartphone } \\
\text { masing-masing }\end{array}$ & 145 & 145 \\
\hline 9 & $\begin{array}{l}\text { Siswa nyaman mengakses materi tentang } A Q \text { di smartphone nya } \\
\text { masing-masing }\end{array}$ & 145 & 141 \\
\hline 10 & $\begin{array}{l}\text { Siswa menyatakan mendukung digitalisasi materi pada layanan } \\
\text { klasikal }\end{array}$ & 145 & 145 \\
\hline & Total Skor & 1450 & 1417 \\
\hline
\end{tabular}

Dari hasil pengamatan didapatkan skor total 1417 dengan skor maksimal 1450, sehingga didapatkan tingkat keaktifan siswa dalam mengikuti bimbingan klasikal dengan media web berbasis google site $97,72 \%$. Berdasarkan pada kriteria tingkat kevalidan dan revisi produk (Ari Kunto, 2006:276) skor 76 -100\% dinyatakan layak dan tidak perlu dilakukan revisi.

\section{PEMBAHASAN}

Untuk meningkatkan kualitas layanan bimbingan klasikal di kelas, guru BK dapat menggunakan media google site. Dengan media yang dihasilkan, peserta didik dapat membuka materi online tidak hanya saat layanan klasikal di kelas, namun mereka juga dapat mengaksesnya kapanpun sesuai dengan keinginan asal ada jaringan internet. Berdasarkan hasil uji kelayakan oleh ahli pengguna dan uji lapangan, media web bimbingan klasikal berbasis google site yang dibuat layak untuk digunakan dalam bimbingan klasikal. Media online bimbingan klasikal berbasis google site telah memenuhi prinsip Access, Cost, Teaching \& Learning functions, Interactive, Organization, Novelty, Speed (ACTIONS). Produk akhir dari kegiatan pengembangan media bimbingan klasikal ini merupakan media interaktif yang diakses melalui jaringan. Tampilan media layaknya website pada umumnya, perbedaannya, link untuk mengakses media bimbingan klasikal berbasis google site diperoleh dari google. Inovasi media menggunakan website google site juga menarik sehingga dapat memotivasi pengguna (peserta didik) untuk aktif mengikuti kegiatan. Hal tersebut sesuai dengan apa yang disampaikan Cobine (dalam sanjaya, 2008:222) bahwa pemanfaatan internet sebagai media pembelajaran mampu 
mengkondisikan dan memotivasi peserta didik untuk belajar secara mandiri. Hasil dari kegiatan pengembangan sekaligus implementasi media berbasis google site ini juga memperkuat penelitian sebelumnya, yaitu penelitian yang berjudul Pengembangan Media Web Bimbingan dan Konseling (Nurita Bangun dan A. Saragih, 2015) yang menyimpulkan bahwa dengan menggunakan fasilitas internet berupa website pada layanan bimbingan dan konseling mampu mempermudah peserta didik dalam mengikuti proses layanan. Kemudahan tersebut memunculkan motivasi keaktifan dalam mengikuti layanan BK sehinggan tujuan layanan akan mudah untuk dicapai. Oleh karena itu, guru BK harus senantiasa mengembangkan kemampuan memberikan pelayanan melalui media yang benar-benar diminati siswa sehingga pelayanan dapat berjalan secara optimal. Sehingga benar yang disampaikan Sink, C. A. (dalam Rakhmawati, D., 2017: 61), bahwa perkembangan di era serba digitalisasi mendorong guru BK untuk melakukan kegiatan: (a) Mengembangkan dan memperbarui keterampilan yang dibutuhkan untuk melayani semua siswa. (b) Menjelajahi inovasi dalam pendidikan dan pemahaman teori konseling kekinian dan cakap dalam mempraktekkannya. Semangat dan usaha guru BK dalam memperbaharui dan mengembangkan keterampilan di era yang serba digital otomatis secara langsung mampu menjawab perubahan perilaku dan karakteristik kekinian peserta didik di era digital.

Secara teknis pembuatan media website dengan memanfaatkan google site sangat mudah, baik untuk guru BK maupun guru mata pelajaran. Tidak diperlukan keterampilan bahasa ataupun kode pemrograman dan juga HTML. Melalui langkah-langkah mudah yang dipaparkan dalam penelitian dan pengembangan ini, guru BK maupun bidang studi dapat membuat website untuk materinya masing-masing. Selain itu, penyusun media web berbasis goole site juga dapat membuat formulir maupun instrumen non testing sebagai asesmen maupun evaluasi yang terintegrasi di halaman site yang dibuat. Sedangkan untuk guru bidang studi, bisa memanfaatkannya sekaligus sebagai media untuk penilaian harian.

\section{KESIMPULAN DAN SARAN}

Tingkat kelayakan dari hasil uji kelayakan 4 (empat) pengguna media mencapai skor yang memuaskan. Pengguna pertama menyatakan media bimbingan yang dibuat sangat layak digunakan dengan persentase sempurna 100\%. Sedangkan pengguna kedua mencapai tingkat kelayakan 94\%. Pengguna ketiga mendapatkan skor kelayakan 84\%. Untuk pengguna keempat mencapai tingkat kelayakan 94\%. Dari uji coba pakar dapat ditarik kesimpulan jika media web bimbingan klasikal berbasis google site sangat layak untuk digunakan. Selain itu media hasil pengembangan sesuai dengan prinsip penggunaan media ACTIONS, yaitu: mudah untuk diakses, ekonomis/murah dalam pembuatan maupun penggunaan, memenuhi tujuan pembelajaran, interaktif dan mudah digunakan, tidak memerlukan persyaratan khusus, memanfaatkan teknologi kekinian, cepat dan mudah.

Sedangkan dari uji lapangan guna mengukur antusiasme dan juga perilaku aktif peserta didik menunjukkan skor yang juga cukup memuaskan. Tingkat partisipasi aktif peserta didik dalam mengikuti kegiatan bimbingan klasikal berbasis google site mencapai 97,72\%. Artinya media google site dapat diterima dan menarik bagi mereka. Berdasarkan data hasil uji kelayakan media oleh pakar yaitu guru BK profesional/bersertifikat pendidik dan data hasil uji 
lapangan (implementasi media yang dihasilkan), menunjukkan bahwa media layanan bimbingan klasikal yang berorientasi kelas dengan menggunakan website google site diterima dan layak untuk diimplementasikan dalam memberikan layanan bimbingan klasikal di kelas.

Dengan mempertimbangkan hasil kegiatan dan implementasi produk media website bimbingan klasikal berbasis google site tersebut disarankan: 1) bagi sejawat guru BK yang membaca laporan ini sangat disarankan untuk menyusun dan mengimplementasikan pada peserta didik/konselinya di tempat bertugasnya masing-masing, tentu saja dengan pertimbangan utama fasilitas internet representatif. Mengingat penyusunannya sangat mudah dan gratis, dapat dibuat google site untuk materi-materi pilihan. Guru BK dalam melaksanakan kegiatan juga langsung dapat melakukan asesmen baik kebutuhan layanan maupun asesmen terkait dengan instrumentasi non testing; 2) sedangkan saran untuk kepala sekolah maupun tim pengembang sekolah, diharapkan mendorong dan memberikan pelatihan guru-guru di sekolah untuk mengembangkan media bimbingan konseling maupun media pembelajaran bidang studi berbasis pengembangan teknologi seperti augmented reality, virtual reality dan yang lainnya sesuai dengan tingkat kemampuan guru dan fasilitas yang tersedia serta mempertimbangkan karakteristik dan ketertarikan peserta didik era sekarang.

\section{DAFTAR RUJUKAN}

Arikunto, Suharsimi. 2006. Prosedur penelitian : suatu pendekatan praktek. Jakarta: Rineka Cipta

Bhakti, Caraka Putra \& dkk, 2018, Blended Learning: Metode Alternatif Dalam Layanan Bimbingan Klasikal, Prosiding Online seminar nasional dan Workshop Bimbingan dan konseling 2018 UNISKA

Bangun, Br Nurita dan Saragih, A Hasan. 2015. Pengembangan Media Web Bimbingan Konseling. Jurnal Teknologi Informasi dan Komunikasi dalam Pendidikan, Vol 2, No 1, Juni 2015, p-ISSn: 2355-4983; e-ISSN: 2407-7488. Diakses pada tanggal 7 Agustus 2019 pada laman https://jurnal.unimed.ac.id/2012/index.php/teknologi/article/view/3285/2953

Bates, A.W. (1995) Technology, open learning and distance education. London: Routledge.

Google site. sagusanove sites. diakses pada 7 Agustus 2019, dari https://sites.google.com/view/sitessagusanov/beranda.

Google site. tutorial site diakses pada 7 Agustus 2019, dari https://Site.google.com/site/tutorialSiteums/definisi

Heinich, R., Molenda, M., dan Russel, J. (2005). Instructional Technology and Media of Learning. New Jersey: Meril Prentice Hall.

Kemendikbud, 2016. Panduan Operasional Penyelenggaraan Bimbingan dan Konseling Sekolah Menengah Atas (SMA). Kementerian Pendidikan dan Kebudayaan Direktorat Jenderal Guru dan Tenaga Kependidikan.

Kemendikbud. 2016. Pedoman BK Pada Pendidikan Dasar dan Pendidikan Menengah. Kementerian Pendidikan dan Kebudayaan Direktorat Jenderal Guru dan Tenaga Kependidikan. 
Kemendikbud. 2008. Peraturan Menteri Pendidikan Nasional Nomor 27 Tahun 2008 tentang Standar Kualifikasi Akademik dan Kompetensi Konselor. Jakarta: Kementerian Pendidikan dan Kebudayaan.

Rakhmawati, Dini. 2017. Konselor Sekolah Abad 21: Tantangan dan Peluang. Jurnal Konseling GUSJIGANG Vol. 3 No. 1 (Januari-Juni 2017) Print ISSBN 2460-1187, Online ISSBN 2503-281X. Diakses pada tanggal 7 Agustus 2019 melalui laman https://jurnal.umk.ac.id/index.php/gusjigang/article/download/1067/1065

Rudi, S., \& Cepi, R. (2008). Media Pembelajaran. Bandung: Jurusan Kurtekpend FIP UPI.

Sanjaya, Wina (2008). Perencanaan Dan Desain Sistem Pembelajaran. Bandung: Kencana

Susana, Tjipto. 2012. Kesetiaan pada Panggilan di Era Digital. Orientasi Baru. Vol. 21. No. 1. Hal. 55-78.

Zimoek, 2016, School Counseling Classroom Guidance: Prevention, Accountability, and Outcomes, Counseling and Professional Identitiy, America. 